\title{
CONSUMERS PRODUCTS AND SERVICES VALUE PERCEPTION
}

\author{
Nichifor Bogdan, Lecturer PhD \\ UNIVERSITY OF BACĂU \\ Barin Ioana, Assistant \\ UNIVERSITY OF BACĂU
}

\begin{abstract}
:
This article is a theoretical approach on products and services as value satisfiers. Consumers have knowledge about the personal, symbolic values that products, services and brands help them satisfy or achieve. Values are people's broad life goals. Values often involve the emotional affect associated with such goals and needs (the strong feelings and emotions that accompany success). Recognizing when a value has been satisfied or a basic life goal has been achieved is an internal feeling that is somewhat intangible and subjective. In contrast, functional and psychosocial consequences are more tangible and are more obvious when they occur. Salespeople add value by identifying customer needs and devising or delivering a solution for those needs. Salespeople are able to adapt how products or/and services are presented or even to adapt products/services so that they meet the needs of the buyers. Such adaption powers professional selling, because customers often don't know what they need or how to configure a solution to their needs. Satisfying a value usually elicits positive affect (happiness, joy, satisfaction), whereas blocking a value produces negative affect (frustration, anger, disappointment). Consumers can have products and services knowledge about products and services attributes, consequences of products or services use and personal values. Most marketing research focuses on one type of products and services knowledge - usually attributes or consequences, where the focus typically is on benefits rather than risks. Values are examined less frequently and usually in isolation. This paper objective is to show the importance of creating, delivering, and capturing buyer value. A company's ability to deliver value to its customers is closely tied with its ability to create satisfaction for its employees and other stakeholders. Value ultimately depends on the perceiver. Smart companies not only offer purchase value but also offer use value as well.
\end{abstract}

\section{Introduction}

Value is defined in the pricing literature as the trade-off between customers' perceptions of benefits received and sacrifices incurred (e.g. Leszinski and Marn, 1997). Monroe (1990) and Gale (1994) cited quality as customers' primary benefit. Monroe (1990) proposed that the sacrifice component exerts the greater influence on buyers' value perceptions. All noted that the role of price is complex and customers do not buy solely on the basis of low price. The context, customers' access to information and past associations also affect price perceptions and consequently customers' value determination (Monroe, 1990).

Other definitions of value have a broader interpretation of sacrifice, in which non-monetary factors such as time and effort are included (e.g. Butz and Goodstein, 1996; Carothers and Adams, 1991; GroÈnroos,
1997; Kotler, 1996; Naumann, 1995; Treacy and Wiersema, 1995; Zeithaml, 1988). Sacrifice is again defined from the customer's perspective, as emphasised by Doyle's (1989, p. 78) definition of value as "not what the producer puts in, but what the consumer gets out".

Many authors have acknowledged the difficulties involved in defining value (e.g. Piercy and Morgan, 1997; Woodruff, 1997). These stem from the subjectivity of value (Hardy, 1987), variations between customers (WikstroÈm and Normann, 1994), within customers (Parasuraman, 1997), between cultures (Assael, 1995), in different situations (Ravald and GroÈnroos, 1996), pre- and postpurchase (Gardial et al., 1994), and between tangible and intangible offerings (Naumann, 1995). 
This is compounded by customer value being a dynamic concept that evolves over time (Jaworski and Kohli, 1993). Indeed it has been claimed that customer value is inherently ambiguous (Naumann, 1995) and that value could be considered "one of the most overused and misused terms in marketing and pricing today" (Leszinski andMarn, 1997, p. 99).

In an attempt to consolidate the diverse definitions, Woodruff (1997, p. 142) proposed: "Customer value is a customer's perceived preference for and evaluation of those product attributes, attribute performances, and consequences arising from use that facilitate (or block) achieving the customer's goals and purposes in use situations". Although the multiple contexts, tasks and criteria in Woodruff's definition reflect the richness and complexity of the concept, they impede its translation into a measurable operational definition (Parasuraman, 1997).

\section{The Four Consumer Buying Behaviors}

Most consumers will adopt all of these buying behaviors, but to varying degrees, behaving in different ways according to the type of product they are purchasing and the purchase situation. However each buying behavior group has different triggers in terms of information, support and persuasion.

\section{Brand-focused}

Marketing communications across the differing buying behavior groups vary enormously. For the brand-focused group, traditional advertising, such as posters, press and TV, will continue to play a part and a key message will be emotional reassurance that they are buying the 'right' brand. The brand should be dominant in all communications, but especially when presenting the brand in nontraditional media such as the internet.

Brand-focused consumers respond to strongly-branded consumer offers and merchandise via the post - good news for the direct marketing industry. But this group requires constant reassurance and the dissemination of information will be particularly vital should the sector undergo rapid change or suffer some crisis.
Maintaining brand trust is critical to this behavior group.

\section{Price-sensitive}

Price-sensitive consumers need to experience value for money at every stage of the buying process. Marketers should build and maintain everyday low-price brand perceptions, and advertising should play a key part in this. Direct communications should be simple, appear inexpensive and emphasise special offers, moneyback deals and price comparisons with competitive brands. And if you want to drive this traditionally less newmedia savvy behavior group on to the internet, demonstrate the low prices they can expect to find there. Everybody loves a bargain but none more so than this group. Communications must highlight value, and news of special prices or invitations to events such as special sales evenings will work well.

\section{Feature-savvy}

Feature-savvy consumers are information-hungry and will respond to direct marketing that offers product information such as comparisons with competitors and independent product reviews. Internet sites are ideal for presenting this information.

Independent editorial will carry greater weight than paid-for advertising, so effective public relations will pay dividends.

Call centre personnel must be highly trained and knowledgeable about the brand they are representing. They should be able to answer complex questions and provide comparative details. Brand is least important to these consumers.

\section{Advice-led}

Personal interaction is key to influencing the buying behavior of advice-led consumers. Testimonials, access to online chat rooms and online shopping guides will also play their part. Word of mouth will be the best reference, and in this respect, telephone operators will need to be both authoritative and reassuring at the same time. Reassurance can also be conveyed through moneyback guarantees and returns policies, and can help to overcome post-purchase dissonance. It is widely anticipated that these buying behaviors can be applied in different markets, although to varying degrees, and the 
communications accordingly.

\section{Consumer Values}

Higher-level needs approach the status of values, which are critical determinants of behaviour (Baier, 1969). Rokeach (1968) regarded a value as "an enduring belief that a specific mode of conduct or end-state of existence is personally or socially preferable to an opposite or converse mode of conduct or end-state of existence'. For Schwartz and Bilsky (1987) values transcend specific situations and one of the most widely accepted value inventory is the Rokeach Value Survey (RVS). The RVS measures 18 instrumental values and the same number of terminal values. Instrumental values are related to preferred modes of conduct such as honesty and friendliness which people know can lead to being accepted by others and to having good relations with others.
Instrumental values are thus means to reach a goal. Terminal values are more related to endstate goals such as wisdom, happiness and freedom.

Instrumental values are: ambitious, broad-minded, capable, cheerful, clean, courageous, forgiving, helpful, honest, imaginative, independent, Intellectual, logical, loving, obedient, polite, responsible, selfcontrolled.

Terminal values are: a comfortable life, an exciting life, a sense of accomplishment, a world at peace, a world of beauty, equality, family security, freedom, happiness, inner harmony, mature love, national security, pleasure, salvation, selfrespect, social recognition, true friendship, wisdom.

Vinson and Lamont (1977) devised a model of consumer value systems (fig.1) by arranging values at three different levels and giving a hierarchical arrangement to them.

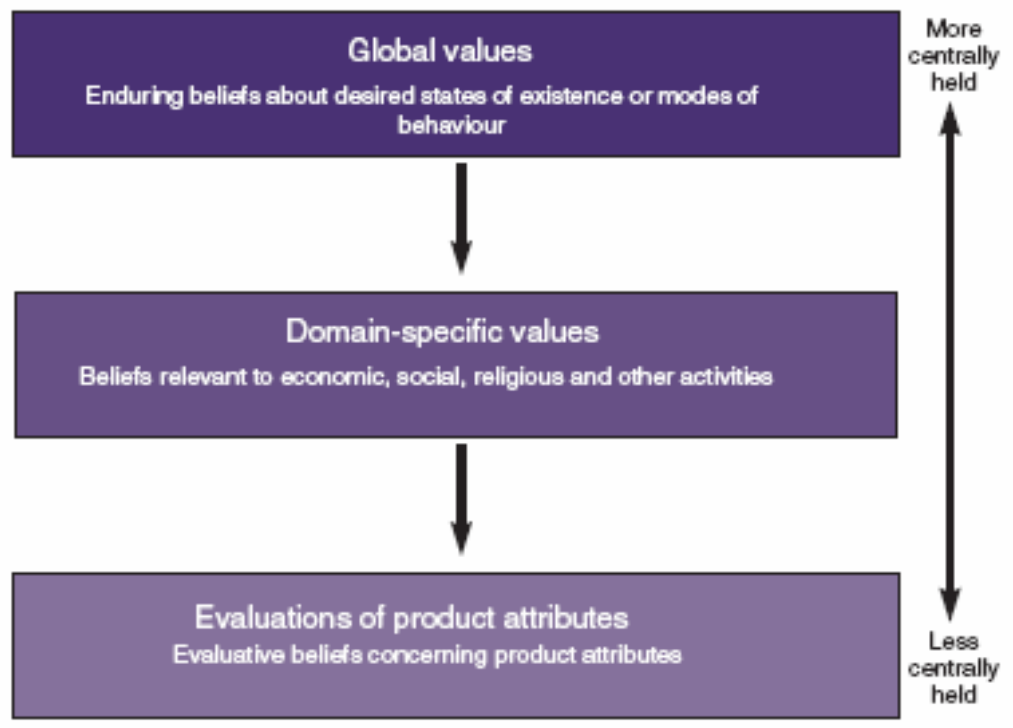

Fig. 1. Consumer value systems

People are not born with their values. Rather, values are passed from one generation to another; they are learned. Engel (1986) point out that some values are relatively constant while others are subject to change.
They propose that the triad of families, religious institutions and school plus early lifetime experiences leads to a model of intergenerational value transmission (Fig. 2). 


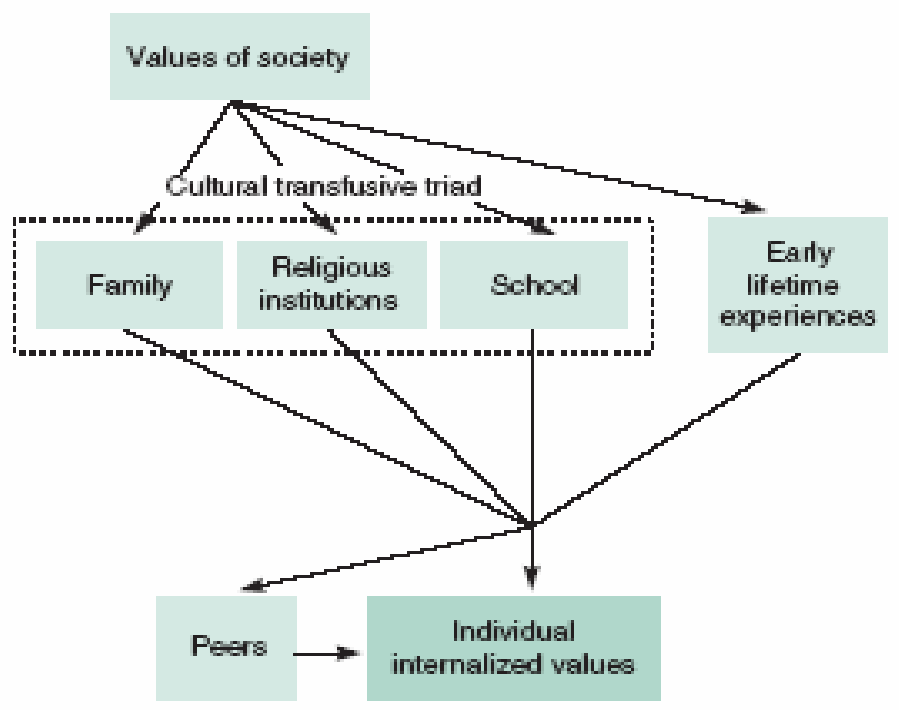

Fig.2. Intergenerational value transmission

\subsection{Products and services quality perceptions}

Products and services quality perceptions represent consumer judgment about the superiority of a product or service, which the user-based approaches think is essential in describing quality. Bundles of attributes together represent a certain level of quality, which therefore provide utility to the customer. The benefits are measured through a perceived level of quality (level of working superiority), a bundle of attributes in comparison with the consumer's expectations. Schiffman and Kanuk (2004) stated consumers often judge the quality of a product on the basis of a variety of informational cues that they associate with the product. They also stated that the cues can either be intrinsic or extrinsic. Intrinsic cues are related to the physical characteristics of the product itself, like size, colour, flavour, aroma etc. The extrinsic cues on the other hand are related to elements that are put together with the actual product like packaging, pricing, advertising etc. The perceived quality of products and services is central to the theory that strong brands add value to consumers' purchase evaluations.

\subsection{Brand Loyalty}

Brand loyalty is the ultimate desired outcome of consumer learning. Brand loyalty is the likelihood of positive attitudes and behaviours of consumers towards a particular brand, this could amount to repeat purchase and positive word of mouth. A loyal customer base is an asset for a company and it reduces the need for seeking new customers. It is also a known fact that retaining current customers requires less money and effort than getting new ones. The strongest measure of brand value is the loyalty a company produces among customers.

Because product quality perceptions influence value, efforts of marketers focus on improving product quality in order to enhance perceptions of value, and consequently purchase intentions leading to loyalty.

\section{Conclusion}

The most functional and fundamental means of identifying a market is by its systems of needs. By literally seeing the purchase decision maker's problem through the decision maker's eyes, it is quite easy to determine:

- what combination of product characteristics represent real value,

- how to communicate the product for the maximum perception of value, and, once that's done,

- how likely the respondent will be to buy. 


\section{References:}

[1] Assael, H. (1995), Consumer Behavior and Marketing Action, 5th ed., South-Western College Publishing, Cincinnati, $\mathrm{OH}$;

[2] Band, W.A. (1991), Creating Value for Customers, John Wiley \& Sons, New York, NY;

[3] Bhat, S. and Reddy, S.K. (1998), "Symbolic and functional positioning of brands", Journal of Consumer Marketing, Vol. 15 No. 1, pp. 32-43;

[4] Brandenburger, A.M. and Stuart, H.W. (1996), "Value-based business strategy", Journal of Economics and Management Strategy, Vol. 5 No. 1, pp. 5-24;

[5] Butz, H.E. and Goodstein, L.D. (1996), "Measuring customer value: gaining the strategic advantage", Organizational Dynamics, Vol. 24, Winter, pp. 63-77;

[6] Carothers, G.H. Jr and Adams, M. (1991), “Competitive advantage through customer value: the role of value-based strategies", in Stahl, M.J. and Bounds, G.M. (Eds), Competing Globally through Customer Value. The Management of Strategic Suprasystems, Quorum Books, New York, NY;

[7] Doyle, P. (1989), "Building successful brands: the strategic objectives", Journal of Marketing Management, Vol. 5 No. 1, pp. 77-95;

[8] Durgee, J.F., O'Connor, G.C. and Veryzer, R.W. (1996), “Observations: translating values into product wants", Journal of Advertising Research, November/December, pp. 90-110;

[9] Engel, J.F., Blackwell, R.D. and Miniard, P.W. (1995), Consumer Behavior, 8th ed., The Dryden Press, Fort Worth, TX;

[10] Farquhar, P.H. (1994), "Strategic challenges for branding", Marketing Management, Vol. 3 No. 2, pp. 8-15;

[11] Fournier, S. and Yao, J.L. (1997), "Reviving brand loyalty: a reconceptualization within the framework of consumer-band relationships", International Journal of Research in Marketing, Vol. 14, pp. 451-72;

[12] Gale, B.Y. (1994), Managing Customer Value. Creating Quality and Service that Customers Can See, The Free Press, New York, NY;

[13] Gardial, S.F., Clemons, D.S., Woodruff, R.B., Schumann, D.W. and Burns, M.J. (1994), 'Comparing consumers' recall of prepurchase and postpurchase product evaluation experiences", Journal of Consumer Research, Vol. 20, March, pp. 548-60;

[14] GroÈnroos, C. (1997), "Value-driven relational marketing: from products to resources and competencies", Journal of Marketing Management, Vol. 13, pp. 407-19;

[15] Hansen, F. (1972), Consumer Choice Behavior: A Cognitive Theory, The Free Press, New York, NY;

[16] Keller, K.L. (1998), Strategic Brand Management. Building, Measuring and Managing Brand Equity, Prentice-Hall, Upper Saddle River, NY;

[17] Kotler, P. (1996), Marketing Management, 9th ed., Prentice-Hall, Upper Saddle River, NY;

[18] Leszinski, R. and Marn, M.V. (1997), "Setting value, not price", The McKinsey Quarterly, Vol. 1, pp. 99-115;

[19] Levitt, T. (1980), "Marketing success through differentiation of anything", Harvard Business Review, January-February, pp. 83-91;

[20] Mathur, S.S. and Kenyon, A. (1997), Creating Value, Butterworth-Heinemann, Oxford. 